\title{
A DIGNIDADE DA PESSOA HUMANA E A JURISPRUDÊNCIA DA CORTE INTERAMERICANA DE DIREITOS HUMANOS
}

\author{
Siddharta Legale \\ Professor de Direito Constitucional da Universidade Federal de Juiz de Fora (UFJF), no \\ campus de Governador Valadares/MG. Doutorando em Direito Internacional pela Univer- \\ sidade do Estado do Rio de Janeiro (Rio de Janeiro/RJ). Mestre em Direito Constitucional \\ e Bacharel pela Universidade Federal Fluminense (Niterói/RJ).
}

\section{Eduardo Manuel Val}

Professor de Direito das Relações Internacionais da Universidade Federal Fluminense (Niterói/RJ), do Programa de Pós-graduação em Direito Constitucional da Universidade Federal Fluminense (Niterói/RJ) e Chefe do Departamento de Direito Público (Niterói/ RJ). Professor do quadro docente permanente do Programa de Mestrado e Doutorado da Universidade Estácio de Sá (Rio de Janeiro/RJ).

\begin{abstract}
Resumo: 0 conteúdo interamericano do princípio da dignidade da pessoa humana será estudado nos tratados de direitos humanos e na jurisprudência da Corte IDH. A dignidade aparece normalmente nos preâmbulos dos tratados na locução "inerente à pessoa humana". Os dispositivos preveem a dignidade ao lado de direitos fundamentais, como a propriedade, vida, integridade física e honra, educação e direitos de grupos em condições de vulnerabilidade, como a mulher e os indígenas. A jurisprudência da Corte IDH costuma empregar pouco a dignidade de forma autônoma. Em geral, a dignidade vem acoplada a um direito humano.
\end{abstract}

Palavras-chave: Dignidade da pessoa humana. Corte Interamericana de Direitos Humanos.

Sumário: 1 Introdução - $\mathbf{2}$ Da filosofia ao direito: a dignidade humana como princípio jurídico - 3 A dignidade da pessoa humana no sistema interamericano de proteção aos direitos humanos $-\mathbf{4} \mathrm{A}$ jurisprudência da Corte Interamericana de Direitos Humanos - 5 Conclusão - Referências

\section{Introdução}

A dignidade da pessoa humana adquiriu uma importância incomensurável dentre os princípios de direito público. No Direito Constitucional, consolidou-se como o princípio fundamental dos ordenamentos jurídicos ocidentais contemporâneos, que confere unidade aos direitos fundamentais. Espraiou-se pelo mundo

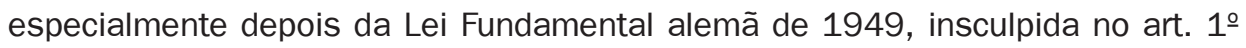


como reação ao nazismo ${ }^{1}$ em uma clara necessidade de proteger a pessoa humana em concreto e não o indivíduo em abstrato contra graves violações aos direitos fundamentais das pessoas, como as que ocorreram com o nazismo. ${ }^{2} \mathrm{~A}$ dignidade tornou-se uma espécie de vedete argumentativa direta ou indireta da fundamentação das decisões de Cortes Constitucionais como se constata em diversos estudos de direito comparado. Nos manuais, a referência é obrigatória ao se discorrer ou comentar minimamente sobre os direitos humanos fundamentais.

No direito internacional, constata-se fenômeno semelhante, desde a previsão da dignidade no preâmbulo e art. $1^{\text {}}$ da Declaração Americana de Direitos e Deveres do Homem e da Declaração Universal de Direitos Humanos da ONU de 1948, que prevê que todos os seres humanos são “iguais em direitos e dignidade". ${ }^{3}$ Há inúmeras referências nos tratados internacionais de direitos humanos à ideia de dignidade. As Cortes Internacionais, em especial de direitos humanos, fazem referência constante a tal noção. É cada vez mais comum nos manuais de direito internacional público e de direito internacional dos direitos humanos. Pairam, porém, muitas dúvidas sobre como interpretar e aplicar a dignidade da pessoa humana nessa encruzilhada do direito constitucional e internacional, entre direitos fundamentais e direitos humanos, em especial no sistema interamericano de proteção dos direitos humanos. A indeterminação conceitual desse princípio, no encontro entre os sistemas nacionais, regionais e globais de proteção aos direitos humanos fundamentais, traz dúvidas sobre o que é concretamente exigivel dos Estados perante a jurisdição internacional.

1 PIEROTH, Bodo; SCHLINK, Bernhard. Direitos fundamentais. São Paulo: Saraiva, 2012, p. 165 e ss.

2 Lei Fundamental de Bonn de 1949, Artigo 1 [Dignidade da pessoa humana - Direitos humanos - Vinculação jurídica dos direitos fundamentais] (1) A dignidade da pessoa humana é intangível. Respeitá-la e protegêla é obrigação de todo o poder público. (2) o povo alemão reconhece, por isto, os direitos invioláveis e inalienáveis da pessoa humana como fundamento de toda comunidade humana, da paz e da justiça no mundo. (3) Os direitos fundamentais, discriminados a seguir, constituem direitos diretamente aplicáveis e vinculam os poderes legislativo, executivo e judiciário. HESSE, Konrad. Elementos de direito constitucional da República Federal da Alemanha. Porto Alegre: Sergio Antonio de Fabris, 1998, p. 109-111. Entre nós, PIOVESAN, Flávia e VIEIRA, Renato Stanziola. A força normativa dos princípios constitucionais fundamentais: a dignidade da pessoa humana. In: PIOVESAN, Flávia (Org.). Temas de direitos humanos. São Paulo: Saraiva, 2010, p. 422. Há quem aponte a Constituição de Weimar, como precursora por conta do art. 151 que dispõe que "A Economia deve ser organizada baseada nos princípios da justiça, com a meta de promover uma vida digna para todos." Também a Constituição Brasileira de 1934 no art. 115 previa, de forma semelhante, que "a ordem econômica deve ser organizada conforme os princípios da Justiça e as necessidades da vida nacional, de modo que possibilite a todos existência digna" É com a Constituição de 1988, que a dignidade da pessoa humana é erigida a princípio fundamental da República no art. 1ํ, III. BARROSO, Luís Roberto. $A$ dignidade da pessoa humana no direito constitucional contemporâneo: a construção de um conceito jurídico à luz da jurisprudência mundial. Belo Horizonte: Fórum, 2014, p. 20 e ss.

3 MCCRUDDEN, Christopher. Human Dignity and Judicial Interpretation of Human Rights. The European Journal of International Law, v. 19, n. 4, 2008 
No conhecido caso do lançamento de anão, por exemplo, a Corte Europeia de Direitos Humanos se recusou a analisar a proibição francesa em relação à "atração" em certos bares que contratavam pessoas com nanismo para serem arremessadas, com base nos princípios da ordem pública e dignidade da pessoa humana. A Corte Europeia entendeu que cada estado possui uma margem de apreciação para conformar tais princípios e não se manifestou sobre o mérito. Qual a norma mais favorável nesse caso? Permitir o trabalho ou proibir o arremesso? A decisão que permite o trabalho estigmatiza os portadores de nanismo em geral ao equipará-los a uma bala? A privação de trabalho do anão viola a dignidade como respeito à autonomia de suas escolhas?

A aplicação da dignidade da pessoa humana por Cortes Internacionais, sem dúvida, desperta inúmeras questões próprias, como, por exemplo, o que é jus cogens, se existe um jus cogens regional, como aplicar a norma pro homine mais favorável ao indivíduo, quando a margem de apreciação nacional deve ser aplicada. As dúvidas que envolvem a aplicação da dignidade da pessoa humana pela jurisdição internacional são muitas. Além de muitas, são complexos os questionamentos decorrentes de suas circunstâncias. Problematizar a questão já pode ser um bom começo, e mostrar que as questões existem já revela a importância da temática. Não pretendemos responder a todos os questionamentos formulados. As perguntas servem para contextualizar o debate sobre a dignidade da pessoa humana em Cortes internacionais e, ao mesmo tempo, incitar o debate temas subteorizados.

Não pretendemos, tampouco, estudar o sistema europeu ou africano de proteção aos direitos humanos. É preciso recortar alguns aspectos para imprimir um maior rigor e precisão. 0 objetivo central do texto será, por isso, mais modesto. A abordagem restringe-se à tentativa de tatear um conceito interamericano de dignidade da pessoa humana ou, pelo menos, como se encara esse princípio na América Latina em especial, a partir dos tratados interamericanos de direitos humanos e da jurisprudência da Corte Interamericana de Direitos Humanos.

Antonio Augusto Cançado Trindade, a respeito, ressalta que a multiplicação de tribunais internacionais e a expansão progressiva de sua jurisdição em nosso tempo são sintomas da tentativa de resolver o conflito pela paz, e não pela força. Mais do que isso, o reconhecimento mais ou menos amplo da titularidade de direito internacional nesse ambiente relaciona-se à busca por realizar a justiça daqueles que não conseguiram ver preservados os seus direitos pela justiça nacional. Destaca a importância da coexistência e coordenação entre as justiças nacional e a internacional e das cortes internacionais entre si para o respeito e efetivação dos direitos humanos. A multiplicação dessas instâncias, como, por exemplo, o Tribunal Penal Internacional, a Corte Europeia de Direitos Humanos, a Corte de 
Justiça das Comunidades Europeias, a Corte Interamericana de Direitos Humanos, pressupõe repensar as formas de proteger à dignidade da pessoa humana ${ }^{4}$.

A Corte IDH tem utilizado de forma tímida ou comedida o conceito e, em geral, associado a outros direitos fundamentais específicos. Os casos mais comuns relacionam-se à violação aos direitos humanos e às obrigações de reparar, relacionadas à violência contra detentos, encarceramento em condições desumanas, desaparecimentos forçados e execuções extrajudiciais. ${ }^{5}$ Ainda assim, há outros casos e dimensões interessantes da proteção à pessoa humana, como, por exemplo, quando a dignidade se imbrica com direitos indígenas, LGBTI e das mulheres.

Preliminarmente, vale ressaltar que existem poucos trabalhos específicos sobre a dignidade da pessoa humana na jurisprudência da Corte Interamericana, ${ }^{6}$ embora existam muitas referências laterais nas decisões da Corte Interamericana, que demandam uma análise mais sistemática. A transversalidade dessa abordagem permitirá compreender a dignidade humana além do Brasil ${ }^{7}$ e aquém do mundo. ${ }^{8}$ Para enfrentar tais questionamentos, será percorrido o seguinte roteiro: (i) uma exposição breve de como a filosofia do direito contemporânea tem abordado a dignidade humana como princípio jurídico; (ii) uma exposição de como a dignidade da pessoa humana aparece nos tratados do sistema interamericano de proteção aos direitos humanos; e (iii) uma exposição de como a jurisprudência da Corte Interamericana aborda tal princípio.

\section{Da filosofia ao direito: a dignidade humana como princípio jurídico}

A dignidade da pessoa humana é um conceito que tem raízes no pensamento de Immanuel Kant. Gradativamente, suas ideias se difundiram a partir da

\footnotetext{
CANÇADO TRINDADE, Antônio Augusto. L'expansion de la juridiction internationale et la sauvegarde de la dignité humaine. In: CANÇADO TRINDADE, Antônio Augusto; LEAL, César Barros (Coord.). Le respect de la dignité humaine: IV Cours Brésilien interdiscipInaire em Droits de I’homme. Fortaleza: IBDH, 2015.

5 BARROSO, Luís Roberto. A dignidade da pessoa humana no direito constitucional contemporâneo: a construção de um conceito jurídico à luz da jurisprudência mundial. Belo Horizonte: Fórum, 2014, p. 32 e ss.

6 CASSETTI, Luisa. I/ diritto di "vivere con dignità" nella giurisprudenza della Corte Interamericana dei Diritti Umani. Disponivel em: <http://www.unipv-lawtech.eu/lang1/files/vivereCONdignita.pdf>. MONSALVE, Viviana Bohórquez; ROMÁN, Javier Aguirre. As tensões da dignidade humana: conceituação e aplicação no direito internacional dos direitos humanos. SUR, v. 6, n. 11, p. 41-63, 2009.

7 Para um trabalho exaustivo sobre as dimensões da dignidade com foco no Brasil, sem prejuízo dos excelentes aportes de direito comparado. Cf. SARMENTO, Daniel. Dignidade da pessoa humana na ordem constitucional brasileira: conteúdo, trajetórias e metodologia. Rio de Janeiro: Tese de Titularidade de Direito Constitucional da UERJ, 2015.

8 BARROSO, Luís Roberto. A dignidade da pessoa humana no direito constitucional contemporâneo: a construção de um conceito jurídico à luz da jurisprudência mundial. Belo Horizonte: Fórum, 2014. BARROSO, Luís Roberto. Aqui, lá e em todo lugar: a dignidade da pessoa humana no direito contemporâneo e no discurso transnacional. Revista dos Tribunais, v. 919, p. 127 e ss, 2012.
} 
simplificação do imperativo de tratar as pessoas como fins e nunca como meios, passando a estar prevista nos Tratados de Direitos Humanos e nas Constituições nacionais. Pretende-se, no presente item, discorrer sobre alguns elementos que integram a noção de dignidade da pessoa humana a partir de uma perspectiva da filosofia do direito. Nesse encontro, a dignidade da pessoa humana pode tanto ser empregada como reforço argumentativo e diretriz hermenêutica, quanto de forma autônoma como princípio fundamental.

Trata-se de um princípio de profunda vagueza semântica, não raro acusado justamente (ou injustamente) por essa amplitude de ser inútil, porque já existiria outra norma de direito fundamental mais específica a ser aplicada. Nesse cenário, alega-se que a dignidade adquire um caráter de mero adorno retórico moral em todas as decisões. Naturalmente, se tudo envolver a dignidade da pessoa humana, nada representará uma proteção da dignidade da pessoa humana. Nesse aspecto, conferir mais precisão ao conceito tende a servir para proteger o que é efetivamente importante. No direito constitucional, isso é particularmente relevante, diante da banalização do uso desse princípio por parte do Poder Judiciário, em especial no Brasil. ${ }^{9}$ No direito internacional, o uso parece mais comedido, pelo menos na Corte IDH. Ainda assim, espera-se que a investigação contribua para que a dignidade ganhe mais consistência no sistema interamericano, ao invés de ser utilizada como mero argumento de reforço.

Superando tais críticas, a doutrina constitucional contemporânea vem procurando refinar os aspectos conceituais, construir parâmetros para racionalizar a sua aplicação e conferir normatividade ao princípio da dignidade da pessoa humana. Destaca que o princípio da dignidade da pessoa humana desempenha, pelo menos, três funções: interpretativa, negativa e direta.

A eficácia interpretativa condiciona o sentido e o alcance das normas jurídicas em geral à "filtragem constitucional" a partir da lente da dignidade da pessoa humana ou, adaptando as reflexões, a partir do direito constitucional internacional, da norma mais favorável ao indivíduo (pro homine).

A eficácia negativa, por sua vez, permite paralisar a eficácia de certas normas por meio da declaração da inconstitucionalidade da norma (controle de constitucionalidade), ou a inconvencionalidade das mesmas (controle de convencionalidade).

A eficácia direta possibilita ao princípio atuar como se regra fosse, por meio do reconhecimento da proteção suficiente ao núcleo de certos direitos fundamentais. Essa dimensão, ainda, é particularmente sensível no sistema interamericano

9 Para um excelente panorama do princípio do Brasil Cf, SARLET, Ingo. Comentário ao art. 1ํㅗ, III. IN: CANTOTILHO, J.J. et al. Comentários à Constituição do Brasil. São Paulo: Saraiva-Almedina, 2013, p. 121 e ss. 
que, em regra, utiliza a dignidade acoplada como desdobramento de outro direito fundamental, como, por exemplo, a vida, honra ou propriedade.

A propósito, vale a pena conferir o conteúdo mínimo para a dignidade da pessoa humana, proposto pelo prof. Luís Roberto Barroso, a partir de três elementos: (i) valor intrínseco; (ii) autonomia; e (iii) valor comunitário. ${ }^{10}$ Uma compreensão do conteúdo mínimo poderá servir para fortalecer a eficácia da dignidade da pessoa humana tanto pela via interpretativa, quanto da eficácia direta.

O valor intrínseco da pessoa humana significa que o ser humano vale por si só e não por uma circunstância, uma habilidade especial ou por um pertencimento a uma casta, dinastia ou grupo social. Decorre da diferença kantiana entre as pessoas e as coisas. ${ }^{11}$ As coisas têm preço, porque podem ser trocadas por outras de igual preço. O ser humano, contrário, não possui preço, não tem outro equivalente que possa substituí-lo. Em outras palavras, o ser humano possui dignidade, um valor incomparável, incondicionado, sem equivalentes, ou seja, um valor. Possui uma dignidade inalienável que impõe dever de respeito à dignidade da humanidade dentro de nós. Tal valor intrínseco proíbe que o ser humano seja utilizado como meio para fins alheios. Nessa linha, Kant constrói uma doutrina das virtudes não apenas como uma doutrina dos deveres, mas como uma doutrina dos fins, "de maneira que um ser humano tem a obrigação de considerar a si mesmo, bem como a todo outro ser humano, como seu fim. Trata-se do que é chamado usualmente de deveres do amor a si mesmo e de amor ao próximo". ${ }^{12}$ Segundo Kant, nem mesmo a punição imposta por um Tribunal tem a faculdade de retirar tal, como se constata na seguinte passagem:

Precisa ser a ele infligida porque cometeu um crime, pois um ser humano nunca pode ser tratado apenas a título de meio para fins

10 BARROSO, Luís Roberto. A dignidade da pessoa humana no direito constitucional contemporâneo: a construção de um conceito jurídico à luz da jurisprudência mundial. Belo Horizonte: Fórum, 2014, p. 72 e ss.

11 KANT, Immanuel. A metafísica dos costumes. Bauru: Edipro, 2008, p. 66: “Uma pessoa é um sujeito cujas ações lhe podem ser imputadas. A personalidade moral não é, portanto, mais do que a liberdade de um ser racional submetido a leis morais (...). Uma coisa é aquilo ao que nada pode ser imputado. Dá-se, portanto, o nome de coisa (res corporalis) a qualquer objeto o livre arbítrio que seja ele próprio carente de liberdade." Em passagem mais ao final da obra, Kant coloca ainda: "Mas um ser humano considerado como um pessoa, isto é, como um sujeito de uma razão moralmente prática, é guindado acima de qualquer preço, pois como pessoa (homo noumenon) não é para ser valorado meramente como um meio para o fim de outros ou menos para seus próprios fins, mas como um fim em si mesmo, isto é, possui dignidade (um valor interno absoluto) através do qual cobra respeito por si mesmo de todos os outros seres racionais do mundo. Pode avaliar a si mesmo conjuntamente a todos os outros seres desta espécie e valorar-se em pé de igualdade com eles" (op. cit, p. 276.) A distinção é retomada ainda ao final do livro, quando Kant afirma que "humanidade ela mesma é uma dignidade" que coloca o ser humano acima das coisas (op. cit., p. 306).

12 KANT, Immanuel. A metafísica dos costumes. Bauru: Edipro, 2008, p. 252-253. 
alheios ou ser colocado entre o objeto do direito das coisas: sua personalidade inata o protege disso, ainda que possa ser condenado à perda de sua personalidade civil. ${ }^{13}$

É verdade que esse valor do ser humano em Kant ainda é compreendido essencialmente como uma decorrência da sua capacidade de exercer vontade racionalmente. ${ }^{14} \mathrm{O}$ argumento destaca a capacidade de pensar como um elemento que nos coloca em posição de igualdade. Todos somos membros do gênero humano. Daí decorre o imperativo de respeito à humanidade em qualquer pessoa como um fim em si mesmo e nunca como meio. ${ }^{15}$ Por óbvio, o valor da humanidade transcende os aspectos racionais para incluir a inteligência, comunicação, sensibilidade, sentimentos, características e outros traços igualmente inerentes à natureza humana. A inviolabilidade de sua dignidade impõe o respeito dos direitos à vida, à igualdade, à integridade física e à integridade moral ou psíquica, mas requer mais do que isso.

A autonomia da vontade constitui outro componente central da dignidade. Pressupõe o respeito à capacidade de autodeterminação e livre capacidade de escolha de cada um. Possui tanto uma dimensão privada, quanto pública. ${ }^{16}$ No aspecto privado, envolve o respeito aos projetos individuais de vida boa, normalmente associados aos direitos individuais, como liberdade de expressão, consciência, crença, etc. No aspecto público, essa autonomia pública se desdobra na possibilidade de influir nos rumos coletivos do país no qual a arena política desempenha um papel central. ${ }^{17}$ Participar, ouvir, ser ouvido na esfera pública é uma expressão da autonomia dos cidadãos no processo de deliberação coletiva sobre as políticas públicas e direitos fundamentais. Essa possibilidade deve concorrer para o amor de si e do próximo, para a felicidade de todos.

13 KANT, Immanuel. A metafísica dos costumes. Bauru: Edipro, 2008, p. 175.

14 KANT, Immanuel. A metafísica dos costumes. Bauru: Edipro, 2008, p. 235: “A faculdade de fixar-se um fim - qualquer que seja - é o que caracteriza a humanidade (enquanto distinta da animalidade). Por conseguinte, está vinculada também ao fim de humanidade em nossa própria pessoa a vontade racional, e assim o dever de tornar a nós mesmos dignos da humanidade pela cultura em geral, no sentido de procurar obter ou estimular a faculdade de realizar todas as modalidades de fins possíveis, na medida em que isso é para ser encontrado num ser humano ele mesmo"

15 KANT, Immanuel. Fundamentação da metafísica dos costumes. Trad. Paulo Quintela. Coimbra: Edições 70,1948, p. 69.

16 KANT, Immanuel. A metafísica dos costumes. Bauru: Edipro, 2008, p. 83: "A liberdade (a independência de ser constrangido pela escolha alheia), na medida em que pode coexistir com liberdade de todos os outros de acordo com uma lei universal, é o único direito original pertencente a todos os homens em virtude da humanidade desses".

17 É interessante a passagem em que Kant destaca que os animais podem ser propriedade do soberano, mas o ser humano, não, porque a qualidade de cidadãos impõe que sejam considerados "membros colegisladores de um Estado (não meramente como meios, mas como fins em si mesmo) e devem oferecer seu livre assentimento através de representantes" KANT, Immanuel. A metafísica dos costumes. Bauru: Edipro, 2008, p. 188. 
Essa noção kantiana da dignidade da pessoa humana em seu aspecto nuclear pode ser traduzida, em termos jurídicos, como o "mínimo existencial" que consubstancia, a um só tempo, pressuposto e finalidade do Estado Democrático de direito que tem a justiça social como fim da ordem econômica. ${ }^{18}$ Nessa encruziIhada do direito constitucional internacional, há uma tensão e reforço mútuo entre autonomia privada e pública.

Por fim, o valor comunitário representa, para Luís Roberto Barroso, os compromissos, valores e crenças do indivíduo inserido em determinado grupo social, envolvendo a comunidade, a Administração pública e o próprio sistema democrático. Em suas próprias palavras, “a dignidade, por essa vertente, não tem na liberdade seu componente central, mas, ao revés, é a dignidade que molda o conteúdo e o limite da liberdade". ${ }^{19}$ A dignidade, como valor comunitário, possui uma dimensão heterônoma. Destina-se a promover objetivos diversos, dentre os quais se destacam: a) a proteção do próprio indivíduo contra atos autorreferentes; b) a proteção de direitos de terceiros; e c) a proteção de valores sociais, inclusive a solidariedade.

Trata-se de uma proposta extremamente clara, objetiva e operacional para a jurisdição constitucional e para a jurisdição em geral: valor intrínseco, autonomia e valor comunitário. Não concordamos, contudo, em integrar o valor comunitário, como elemento constitutivo da dignidade da pessoa humana. O valor comunitário representa muito mais um limite à autonomia e, portanto, à própria dignidade humana. Por outro lado, as reflexões presentes nesse item não podem simplesmente ser descartadas sem levar em consideração a dimensão intersubjetiva ou construída socialmente da dignidade que transcende a dimensão simplesmente ontológica da dignidade (valor intrínseco e autonomia). ${ }^{20}$

Mais consistente nesse aspecto, por isso, revela-se a tese de titularidade de Daniel Sarmento, quando propõe os seguintes elementos centrais para dignidade da pessoa humana: (i) valor intrínseco; (ii) autonomia; (iii) mínimo existencial; e (iv) reconhecimento. ${ }^{21}$ Em linhas gerais, Daniel Sarmento destaca como, historicamente, a dignidade deixa de ser um privilégio de uma minoria e se torna um princípio universal, preocupado, não com o sujeito abstrato, mas com a pessoa

18 SILVA, José Afonso da. A dignidade da pessoa humana como valor supremo da democracia. In: Poder Constituinte e poder popular. São Paulo: Malheiros, 2007, p. 144 e ss.

19 BARROSO, Luís Roberto. A dignidade da pessoa humana no direito constitucional contemporâneo: a construção de um conceito jurídico à luz da jurisprudência mundial. Belo Horizonte: Fórum, 2014, p. 28.

20 Sobre as dimensões ontológica e intersubjetiva, Cf. SARLET, Ingo. As dimensões da dignidade da pessoa humana: construindo uma compreensão jurídico constitucional necessária e possível. Revista Brasileira de Direito Constitucional n. 09, 2007.

21 SARMENTO, Daniel. Dignidade da pessoa humana na ordem constitucional brasileira: conteúdo, trajetórias e metodologia. Rio de Janeiro: Tese de Titularidade de Direito Constitucional da UERJ, 2015, p. 87 e ss. 
concreta e socialmente enraizada. A ideia originalmente religiosa e filosófica tornase uma norma jurídica vinculante com os elementos mencionados. Os dois primeiros elementos já foram abordados de forma suficiente para a limitada pretensão desse trabalho. Vejamos os dois últimos.

O mínimo existencial é apresentado a partir de três visões. ${ }^{22}$ A primeira, na linha do Pensamento de John Rawls, compreende o mínimo como mínimo social, uma condição para o exercício das liberdades primárias. ${ }^{23} \mathrm{~A}$ segunda, na linha de Jürgen Habermas, descreverá o mínimo como condições para participação em uma sociedade democrática. ${ }^{24} \mathrm{~A}$ terceira, perfilhando o pensamento de Ernest Tugendat, descreverá o mínimo como necessidades básicas. O prof. Daniel Sarmento pontua que as duas primeiras condicionam o mínimo existencial à liberdade ou à democracia, enquanto a última trata o mínimo como um argumento independente. Rejeita tentativas de definir com precisão o conceito de mínimo existencial ${ }^{25}$ com objetivo de, mantendo a sua natural abertura, preservar necessidades vitais básicas variadas, como até mesmo o meio ambiente, sem o qual não há vida digna.

O direito fundamental ao reconhecimento nasce como um desdobramento da dignidade humana, igualdade e solidariedade. Em sua faceta negativa, veda práticas que desrespeitem a identidade das pessoas ou as estigmatizem. Em seu aspecto positivo, impõe medidas para combater, vedar e superar esses estigmas, preconceitos e discriminações. Trata-se de um imperativo de adaptação ou acomodação razoável das minorias ou grupos vulneráveis, como deficientes, minorias religiosas ou povos indígenas. Como bem destaca Daniel Sarmento, a "falta de reconhecimento oprime, instaura hierarquias, frustra a autonomia e causa sofrimento". Essa falta de reconhecimento sistemática traz reflexos para as relações econômicas e sociais, ao reduzir oportunidades a certos grupos e a dificultar 0 acesso a posições. Note-se que essa dimensão do princípio da dignidade da pessoa humana acentua o que há de intersubjetivo na dignidade a partir da noção de reconhecimento.

É verdade que alguns elementos comuns entre as análises de Barroso e de Sarmento, como o mínimo existencial que, para Barroso, estaria no interior

22 Para uma visão mais ampla sobre o mínimo e seus aspectos conceituais, Cf. LOBO TORRES, Ricardo. $O$ Direito ao mínimo existencial. Rio de Janeiro: Renovar, 2009, p. 35 e ss.

23 RAWLS, John. Uma teoria da justiça. São Paulo: Martins Fontes, 2008, p. 239-488. RAWLS, John. Justiça como equidade: uma reformulação. São Paulo: Martins Fontes, 2003, p. 12-18 e p. 30 e 33.

24 HABERMAS, Jurgen. Sobre a coesão interna entre Estado de direito e democracia. In: $A$ inclusão do outro, estudos de teoria política. São Paulo: Edições Loyola, 2007, p. 293-298.

25 Concebendo o mínimo como educação fundamental, saúde básica, assistência social e acesso à justiça, Cf. BARCELLOS, Ana Paula de. A eficácia jurídica dos princípios constitucionais: o princípio da dignidade da pessoa humana. Rio de Janeiro: Renovar, 2002, p. 305 e ss. 
da autonomia como elemento da dignidade. Ainda assim, a arrumação proposta por Sarmento tem o mérito de construir um conceito de dignidade da pessoa humana de forma mais coerente do ponto de vista filosófico, a partir da noção de dignidade como autonomia em bases menos individualistas. 0 destaque conferido pelo autor ao mínimo existencial e ao reconhecimento, nesse sentido, acentua a dimensão intersubjetiva da dignidade e atenta para violações ao igual respeito e consideração de todos os seres humanos, o que é particularmente relevante para o Brasil e para América Latina.

Adotaremos uma combinação entre o pensamento de Barroso e Sarmento para ler a dignidade na pessoa humana no sistema interamericano: (i) valor intrínseco; (ii) autonomia; e (iii) reconhecimento. ${ }^{26}$ Em primeiro lugar, a abordagem se justifica, porque no plano interno da jurisdição constitucional, a dignidade humana como mínimo existencial é utilizada para judicialização de direitos sociais com mais intensidade do que no plano internacional das Cortes de Direitos Humanos. Em segundo lugar, a ideia de reconhecimento traduz melhor do que a expressão valor comunitário as preocupações contemporâneas dos tratados interamericanos de direitos humanos com a proteção de minorias ou grupos em situação de vulnerabilidade, como crianças, deficientes, negros, índios, mulheres, gays, lésbicas, transexuais e intersexuais.

\section{A dignidade da pessoa humana no sistema interamericano de proteção aos direitos humanos}

A dignidade da pessoa humana é um princípio que possui uma importante função interpretativa no sistema interamericano de proteção aos direitos humanos. É o que se constata pelo fato de a "dignidade", a "pessoa humana", "direitos da pessoa", "dignidade da pessoa humana", "dignidade inerente à pessoa humana" ou apenas o "ser humano" aparecer de variadas formas na maioria dos preâmbulos de variadas Convenções interamericanas destinadas à proteção dos direitos humanos.

Os preâmbulos, embora desprovidos para alguns de normatividade, ${ }^{27}$ possuem geralmente relevante função hermenêutica por desvelar as intenções subjacentes às Constituições. Em relação aos tratados, costumam auxiliar na

26 Optei por diluir o mínimo existencial dentre uma dessas três facetas.

27 No Brasil, compreende-se que o preâmbulo não tem força normativa, mas apenas interpretativa, conforme ficou decidido em conhecido caso que não se declarou a inconstitucionalidade do preâmbulo da Constituição do Acre que não reproduziu o "sob a proteção de Deus", optando por empregar a expressão "inspirados nos heróis da revolução acreana”. Cf. STF, ADI № 2076, Rel. Min. Carlos Velloso, J. 15.08.2002. 
compreensão de seu contexto, conforme prevê o art. 31 da Convenção de Viena. ${ }^{28}$ A partir dos preâmbulos e dos dispositivos do corpo das Convenções que preveem a dignidade explicitamente, destacaremos inicialmente como o sistema interamericano dispõe sobre as diferentes dimensões da dignidade da pessoa humana quanto ao (i) valor intrínseco; (ii) autonomia; e (iii) reconhecimento.

Em primeiro lugar, o valor intrínseco da pessoa humana está presente em diversos preâmbulos das declaração e convenções interamericanas. Em geral, designa-se o valor intrínseco pelas expressões "dignidade inerente à pessoa humana", "inerente a todo ser humano" e das expressões "iguais em dignidade", presente sistematicamente nas convenções interamericanas, como a Declaração Americana dos Direitos e Deveres do Homem de $1948,{ }^{29}$ Convenção Interamericana para Prevenir e Punir a Tortura de 1985 , $^{30}$ Convenção Interamericana para a Eliminação de Todas as Formas de Discriminação contra as Pessoas Portadoras de Deficiência de $1999^{31}$ e na Convenção Interamericana contra o Racismo, a Discriminação Racial e Formas Correlatas de Intolerância de 2013. ${ }^{32}$

28 No plano internacional, o tratado deve ser interpretado de boa-fé e à luz de seu contexto, objetivo e finalidade, incluindo-se no "contexto" não só o texto, anexos e instrumentos conexos, mas também o preâmbulo, conforme dispõe o art. 31 da Convenção de Viena de Direito dos Tratados de 1969.

29 Perceba-se, que, no preâmbulo da Declaração Americana dos Direitos e Deveres do Homem de 1948 , a dignidade aparece como uma característica de todos os homens que nascem livres e iguais e cujos deveres exprimem a dignidade dessa liberdade. Confira-se: Preâmbulo: “Todos os homens nascem livres e iguais em dignidade e direitos e, como são dotados pela natureza de razão e consciência, devem proceder fraternalmente uns para com os outros. O cumprimento do dever de cada um é exigência do direito de todos. Direitos e deveres integram-se correlativamente em toda a atividade social e política do homem. Se os direitos exaltam a liberdade individual, os deveres exprimem a dignidade dessa liberdade".

30 Note-se, que, no preâmbulo da Convenção Interamericana para Prevenir e Punir a Tortura de 1985, a dignidade humana repele todo ato de tortura ou tratamentos ou penas cruéis, desumanos ou degradantes, reafirmando a "dignidade inerente à pessoa humana" e a necessidade de assegurar o exercício pleno de liberdades e direitos fundamentais. Confira-se: "Reafirmando que todo ato de tortura ou outros tratamentos ou penas cruéis, desumanos ou degradantes constituem uma ofensa à dignidade humana e uma negação dos princípios consagrados na Carta da Organização dos Estados Americanos e na Carta das Nações Unidas, e são violatórios dos direitos humanos e liberdades fundamentais proclamados na Declaração Americana dos Direitos e Deveres do Homem e na Declaração Universal dos Direitos do Homem; Reiterando seu propósito de consolidar neste Continente as condições que permitam o reconhecimento e o respeito da dignidade inerente à pessoa humana e assegurem o exercício pleno de suas liberdades e direitos fundamentais".

31 Convenção Interamericana para a Eliminação de Todas as Formas de Discriminação contra as Pessoas Portadoras de Deficiência (1999), Preâmbulo: “Reafirmando que as pessoas portadoras de deficiência têm os mesmos direitos humanos e liberdades fundamentais que outras pessoas e que estes direitos, inclusive o direito de não ser submetidas a discriminação com base na deficiência, emanam da dignidade e da igualdade que são inerentes a todo ser humano".

32 Convenção Interamericana contra o Racismo, a Discriminação Racial e Formas Correlatas de Intolerância de 2013, Preâmbulo: “OS ESTADOS PARTES NESTA CONVENÇÃO, CONSIDERANDO que a dignidade inerente e a igualdade de todos os membros da família humana são princípios básicos da Declaração Universal dos Direitos Humanos, da Declaração Americana dos Direitos e Deveres do Homem, da Convenção Americana sobre Direitos Humanos e da Convenção Internacional sobre a Eliminação de Todas as Formas de Discriminação Racial". 
Vale a pena conferir, ainda, o preâmbulo da Convenção Interamericana sobre Desaparecimento Forçado de Pessoas de 1994. A dignidade inerente à pessoa humana possui caráter irrevogável e impõe o reconhecimento de que o desaparecimento forçado viola múltiplos direitos fundamentais, constituindo um crime de lesa-humanidade. ${ }^{33}$

Dentre as Convenções, merece destaque pela clareza o preâmbulo da Convenção Americana sobre Direitos Humanos de 1969, também conhecida como Pacto de São José da Costa Rica. É nele que o valor intrínseco da pessoa humana fica melhor expresso, porque exibe uma declaração de que a exigência de proteção dos direitos do homem deriva não de ser nacional de determinado Estado, mas sim pelo "fato de ter como fundamento os atributos da pessoa humana". ${ }^{34}$ Decorre desse imperativo a proteção convencional, coadjuvante ou complementar ao direito interno pelo único fato de existir e não porque a pessoa possui um talento especial ou porque integra uma casta, etnia ou grupo. Em outras palavras, a dignidade não é construída, mas sim é inerente à pessoa humana.

Nesse sentido, a dignidade consta, no corpo da Convenção, explicitamente relacionada ao direito à integridade pessoal e à vedação à tortura, a penas cruéis, desumanas ou degradantes (art. $5^{\text {o5 }}$ ), à proibição da escravidão, da servidão e a

33 Convenção Interamericana sobre o Desaparecimento Forçado de Pessoas de 1994, Preâmbulo: "REAFIRMANDO que o verdadeiro sentido da solidariedade americana e da boa vizinhança só pode ser o de consolidar neste Hemisfério, no quadro das instituições democráticas, um regime de liberdade individual e de justiça social, fundado no respeito dos direitos essenciais do homem;

CONSIDERANDO que o desaparecimento forçado de pessoas constitui uma afronta à consciência do Hemisfério e uma grave ofensa de natureza hedionda à dignidade inerente à pessoa humana, em contradição com os princípios e propósitos consagrados na Carta da Organização dos Estados Americanos;

CONSIDERANDO que o desaparecimento forçado de pessoas viola múltiplos direitos essenciais da pessoa humana, de caráter irrevogável, conforme consagrados na Convenção Americana sobre Direitos Humanos, na Declaração Americana dos Direitos e Deveres do Homem e na Declaração Universal dos Direitos Humanos;

RECORDANDO que a proteção internacional dos direitos humanos é de natureza convencional coadjuvante ou complementar da que oferece o direito interno, e tem como fundamento os atributos da pessoa humana; REAFIRMANDO que a prática sistemática do desaparecimento forçado de pessoas constitui um crime de lesa-humanidade".

34 Convenção Americana sobre Direitos Humanos de 1969, Preâmbulo: "Reconhecendo que os direitos essenciais do homem não derivam do fato de ser ele nacional de determinado Estado, mas sim do fato de ter como fundamento os atributos da pessoa humana, razão por que justificam uma proteção internacional, de natureza convencional, coadjuvante ou complementar da que oferece o direito interno dos Estados americanos".

35 Convenção Americana Sobre Direitos Humanos de 1969, "Artigo 5. Direito à integridade pessoal 1. Toda pessoa tem o direito de que se respeite sua integridade física, psíquica e moral. 2. Ninguém deve ser submetido a torturas, nem a penas ou tratos cruéis, desumanos ou degradantes. Toda pessoa privada da liberdade deve ser tratada com o respeito devido à dignidade inerente ao ser humano. 3. A pena não pode passar da pessoa do delinqüente. 4. Os processados devem ficar separados dos condenados, salvo em circunstâncias excepcionais, e ser submetidos a tratamento adequado à sua condição de pessoas não condenadas. 5 . Os menores, quando puderem ser processados, devem ser separados dos 
necessidade de preservar a dignidade humana do recluso (art. 6ํ6), à proteção da honra, vida privada e reputação contra ingerências e ofensas ilegais (art. $11^{37}$ ).

Em relação à autonomia como elemento da dignidade humana, vale atentar para o preâmbulo do Protocolo adicional à Convenção Americana sobre Direitos Humanos em matéria de Direitos Econômicos, Sociais e Culturais de 1988, também conhecido como Protocolo de Salvador. Ele chama atenção para a interdependência que existe entre direitos ditos de primeira geração (civis e políticos) e de segunda geração (econômicos, sociais e culturais). Destaca, expressamente, que "as diferentes categorias de direito constituem um todo indissolúvel que encontra sua base no reconhecimento da dignidade da pessoa humana", bem como a necessidade "de consolidar na América, com base no respeito pleno dos direitos da pessoa, o regime democrático representativo de governo, bem como o direito de seus povos ao desenvolvimento, à livre determinação e a dispor livremente de suas riquezas e recursos naturais".

Em outras palavras, tanto a autonomia privada, quanto a pública são fundamentais para a proteção da dignidade da pessoa humana. De um lado, a dignidade como autonomia privada encontra consistente formulação na Declaração Americana dos Direitos e Deveres do Homem de 1948 que associa a "dignidade da pessoa e do lar" ao direito de propriedade apto a manter as "necessidades essenciais de uma vida decente" (art. XXIII ${ }^{38}$ ).

adultos e conduzidos a tribunal especializado, com a maior rapidez possível, para seu tratamento. 6 . As penas privativas da liberdade devem ter por finalidade essencial a reforma e a readaptação social dos condenados".

36 "Artigo 6. Proibição da escravidão e da servidão 1. Ninguém pode ser submetido a escravidão ou a servidão, e tanto estas como o tráfico de escravos e o tráfico de mulheres são proibidos em todas as suas formas. 2. Ninguém deve ser constrangido a executar trabalho forçado ou obrigatório. Nos países em que se prescreve, para certos delitos, pena privativa da liberdade acompanhada de trabalhos forçados, esta disposição não pode ser interpretada no sentido de que proíbe o cumprimento da dita pena, imposta por juiz ou tribunal competente. 0 trabalho forçado não deve afetar a dignidade nem a capacidade física e intelectual do recluso. 3. Não constituem trabalhos forçados ou obrigatórios para os efeitos deste artigo: a. os trabalhos ou serviços normalmente exigidos de pessoa reclusa em cumprimento de sentença ou resolução formal expedida pela autoridade judiciária competente. Tais trabalhos ou serviços devem ser executados sob a vigilância e controle das autoridades públicas, e os indivíduos que os executarem não devem ser postos à disposição de particulares, companhias ou pessoas jurídicas de caráter privado; b. o serviço militar e, nos países onde se admite a isenção por motivos de consciência, o serviço nacional que a lei estabelecer em lugar daquele; c. o serviço imposto em casos de perigo ou calamidade que ameace a existência ou o bem-estar da comunidade; e d. o trabalho ou serviço que faça parte das obrigações cívicas normais."

37 "Artigo 11. Proteção da honra e da dignidade 1. Toda pessoa tem direito ao respeito de sua honra e ao reconhecimento de sua dignidade. 2. Ninguém pode ser objeto de ingerências arbitrárias ou abusivas em sua vida privada, na de sua família, em seu domicílio ou em sua correspondência, nem de ofensas ilegais à sua honra ou reputação. 3 . Toda pessoa tem direito à proteção da lei contra tais ingerências ou tais ofensas."

38 Declaração Americana dos Direitos e Deveres do Homem de 1948, "Artigo XXIII. Toda pessoa tem direito à propriedade particular correspondente às necessidades essenciais de uma vida decente, e que contribua a manter a dignidade da pessoa e do lar". 
Por outro lado, o Protocolo de San Salvador consigna, em afinada harmonia com a autonomia privada, a dignidade como autonomia pública a partir do direito à educação. Determina que a educação deve capacitar todos as pessoas para o pleno desenvolvimento da personalidade humana e do sentido de sua dignidade, bem como para participar efetivamente de uma sociedade democrática e pluralista (art. 13, 2). ${ }^{39}$

Por fim, quanto à dimensão mais intersubjetiva, relacionada especialmente ao reconhecimento, é possível destacar situações específicas de direitos humanos relacionados às mulheres, aos negros, aos índios e outros grupos em situações de vulnerabilidade. Destaca-se, inicialmente, o preâmbulo da Convenção Interamericana para prevenir, punir e erradicar a violência contra a mulher de 1994, também conhecida como Convenção de Belém do Pará. Pontua-se, aqui, a violência contra a mulher como uma ofensa à dignidade humana e de relações historicamente desiguais. Perceba-se que, a partir dessa Convenção, a dignidade começa a adquirir um caráter mais concreto e palpável, que busca empoderar o ser humano em suas circunstâncias concretas, na construção de sua identidade intersubjetivamente e não mais de forma abstrata. ${ }^{40}$

A Convenção de Belém do Pará de 1994, sem dúvida, representa um marco muito relevante no sistema interamericano na compreensão da dignidade humana, especialmente, quando trata do tema diretamente em dois artigos que dispõem sobre a dignidade da mulher. 0 art. 4 positiva o direito ao reconhecimento, desfrute, exercício e proteção de todos os direitos humanos e liberdades, destacando o direito à vida, segurança e integridade física, mental e moral. É interessante notar a alínea "e" como um chamamento ao respeito à "dignidade inerente à sua pessoa e a que se proteja sua família". ${ }^{41} \mathrm{O}$ art. $8^{\circ}$, por sua vez, destaca os programas e

39 Protocolo Adicional à Convenção Americana Sobre Direitos Humanos em matéria de Direitos Econômicos, Sociais e Culturais, de 1988, "Artigo 13 Direito à educação 1. Toda pessoa tem direito à educação. E 2. Os Estados Partes neste Protocolo convêm em que a educação deverá orientar-se para o pleno desenvolvimento da personalidade humana e do sentido de sua dignidade e deverá fortalecer o respeito pelos direitos humanos, pelo pluralismo ideológico, pelas liberdades fundamentais, pela justiça e pela paz. Convêm, também, em que a educação deve capacitar todas as pessoas para participar efetivamente de uma sociedade democrática e pluralista, conseguir uma subsistência digna, favorecer a compreensão, a tolerância e a amizade entre todas as nações e todos os grupos raciais, étnicos ou religiosos e promover as atividades em prol da manutenção da paz".

40 Convenção de Belém do Pará de 1994, Preâmbulo: "PREOCUPADOS por que a violência contra a mulher constitui ofensa contra a dignidade humana e é manifestação das relações de poder historicamente desiguais entre mulheres e homens".

41 Convenção Interamericana para Prevenir, Punir e Erradicar a Violência Contra A Mulher, de 1994, "Artigo 4 Toda mulher tem direito ao reconhecimento, desfrute, exercício e proteção de todos os direitos humanos e liberdades consagrados em todos os instrumentos regionais e internacionais relativos aos direitos humanos. Estes direitos abrangem, entre outros: a. direito a que se respeite sua vida; b. direito a que se respeite sua integridade física, mental e moral; c. direito à liberdade e à segurança pessoais; $d$. direito a não ser submetida a tortura; e. direito a que se respeite a dignidade inerente à sua pessoa e a que se proteja sua família; f. 
as medidas específicas dirigidas às instituições de educação, ao Poder Judiciário, à polícia e aos meios de comunicação para combater preconceitos, costumes e práticas baseadas na premissa da inferioridade ou superioridade de qualquer dos gêneros ou nos papéis estereotipados para o homem e a mulher. 0 art. 8 "g" incentiva que os meios de comunicação formulem diretrizes que contribuam para erradicação da violência contra a mulher e enalteçam o "respeito pela dignidade da mulher". 42

No mesmo sentido, o preâmbulo da Convenção Interamericana contra o Racismo, a Discriminação Racial e formas Correlatas de Intolerância, de 2013, reafirma a dignidade inerente e a igualdade de todos os membros da família humana, vedando o racismo, a discriminação e a intolerância por representarem a negação de "valores universais e de direitos inalienáveis e invioláveis da pessoa humana". O ponto mais interessante do preâmbulo da Convenção, porém, referese ao reconhecimento de que certos grupos, minoritários ou não, vivenciam formas múltiplas e extremas de racismo, discriminação e intolerância por conta de fatores, como "raça, cor, ascendência, origem nacional ou étnica", que prejudicam a possibilidade de "expressar, preservar e desenvolver sua identidade" individual ou coletivamente, de modo que é necessário "proteger o projeto de vida de indivíduos e comunidades em risco de exclusão e marginalização". ${ }^{43}$

direito a igual proteção perante a lei e da lei; g. direito a recurso simples e rápido perante tribunal competente que a proteja contra atos que violem seus direitos; h. direito de livre associação; i. direito à liberdade de professar a própria religião e as próprias crenças, de acordo com a lei; e j. direito a ter igualdade de acesso às funções públicas de seu país e a participar nos assuntos públicos, inclusive na tomada de decisões".

42 "Artigo 80 s Estados Partes convêm em adotar, progressivamente, medidas específicas, inclusive programas destinados a: (...) g. incentivar os meios de comunicação a que formulem diretrizes adequadas de divulgação, que contribuam para a erradicação da violência contra a mulher em todas as suas formas e enalteçam o respeito pela dignidade da mulher,"

43 Convenção Interamericana contra o Racismo, a Discriminação Racial e Formas Correlatas de Intolerância de 2013, Preâmbulo: “OS ESTADOS PARTES NESTA CONVENÇÃO, CONSIDERANDO que a dignidade inerente e a igualdade de todos os membros da família humana são princípios básicos da Declaração Universal dos Direitos Humanos, da Declaração Americana dos Direitos e Deveres do Homem, da Convenção Americana sobre Direitos Humanos e da Convenção Internacional sobre a Eliminação de Todas as Formas de Discriminação Racial;

REAFIRMANDO o firme compromisso dos Estados membros da Organização dos Estados Americanos com a erradicação total e incondicional do racismo, da discriminação racial e de todas as formas de intolerância, e sua convicção de que essas atitudes discriminatórias representam a negação dos valores universais e dos direitos inalienáveis e invioláveis da pessoa humana e dos propósitos e princípios consagrados na Carta da Organização dos Estados Americanos, na Declaração Americana dos Direitos e Deveres do Homem, na Convenção Americana sobre Direitos Humanos, na Carta Social das Américas, na Carta Democrática Interamericana, na Declaração Universal dos Direitos Humanos, na Convenção Internacional sobre a Eliminação de Todas as Formas de Discriminação Racial e na Declaração Universal sobre o Genoma Humano e os Direitos Humanos;

CONVENCIDOS de que determinadas pessoas e grupos vivenciam formas múltiplas ou extremas de racismo, discriminação e intolerância, motivadas por uma combinação de fatores como raça, cor, ascendência, origem nacional ou étnica, ou outros reconhecidos em instrumentos internacionais; 


\section{Nessa Convenção, a dignidade é associada à proteção contra a intolerância e} a discriminação racional direta, indireta ou múltipla, baseadas em características, opiniões ou convicções das pessoas, que possam operar em relação a certos grupos, especialmente os em condições de vulnerabilidade, num processo de marginalização e exclusão da participação nas esferas da vida pública ou privada (art. 1ํ4). A dignidade aparece, ainda, como uma vedação à realização ou uso de

LEVANDO EM CONTA que uma sociedade pluralista e democrática deve respeitar a raça, cor, ascendência e origem nacional ou étnica de toda pessoa, pertencente ou não a uma minoria, bem como criar condições adequadas que the possibilitem expressar, preservar e desenvolver sua identidade;

CONSIDERANDO que a experiência individual e coletiva de discriminação deve ser levada em conta para combater a exclusão e a marginalização com base em raça, grupo étnico ou nacionalidade e para proteger o projeto de vida de indivíduos e comunidades em risco de exclusão e marginalização;

ALARMADOS com o aumento dos crimes de ódio motivados por raça, cor, ascendência e origem nacional ou étnica;

RESSALTANDO o papel fundamental da educação na promoção do respeito aos direitos humanos, da igualdade, da não discriminação e da tolerância; e

TENDO PRESENTE que, embora o combate ao racismo e à discriminação racial tenha sido priorizado em um instrumento internacional anterior, a Convenção Internacional sobre a Eliminação de Todas as Formas de Discriminação Racial, de 1965, os direitos nela consagrados devem ser reafirmados, desenvolvidos, aperfeiçoados e protegidos, a fim de que se consolide nas Américas o conteúdo democrático dos princípios da igualdade jurídica e da não discriminação".

44 Convenção Interamericana contra o Racismo, a Discriminação Racial e Formas Correlatas de Intolerância de 2013, "Artigo 1 Para os efeitos desta Convenção: 1. Discriminação racial é qualquer distinção, exclusão, restrição ou preferência, em qualquer área da vida pública ou privada, cujo propósito ou efeito seja anular ou restringir o reconhecimento, gozo ou exercício, em condições de igualdade, de um ou mais direitos humanos e liberdades fundamentais consagrados nos instrumentos internacionais aplicáveis aos Estados Partes. A discriminação racial pode basear-se em raça, cor, ascendência ou origem nacional ou étnica. 2. Discriminação racial indireta é aquela que ocorre, em qualquer esfera da vida pública ou privada, quando um dispositivo, prática ou critério aparentemente neutro tem a capacidade de acarretar uma desvantagem particular para pessoas pertencentes a um grupo específico, com base nas razões estabelecidas no Artigo 1.1, ou as coloca em desvantagem, a menos que esse dispositivo, prática ou critério tenha um objetivo ou justificativa razoável e legítima à luz do Direito Internacional dos Direitos Humanos. 3. Discriminação múltipla ou agravada é qualquer preferência, distinção, exclusão ou restrição baseada, de modo concomitante, em dois ou mais critérios dispostos no Artigo 1.1, ou outros reconhecidos em instrumentos internacionais, cujo objetivo ou resultado seja anular ou restringir o reconhecimento, gozo ou exercício, em condições de igualdade, de um ou mais direitos humanos e liberdades fundamentais consagrados nos instrumentos internacionais aplicáveis aos Estados Partes, em qualquer área da vida pública ou privada. 4. Racismo consiste em qualquer teoria, doutrina, ideologia ou conjunto de ideias que enunciam um vínculo causal entre as características fenotípicas ou genotípicas de indivíduos ou grupos e seus traços intelectuais, culturais e de personalidade, inclusive o falso conceito de superioridade racial. 0 racismo ocasiona desigualdades raciais e a noção de que as relações discriminatórias entre grupos são moral e cientificamente justificadas. Toda teoria, doutrina, ideologia e conjunto de ideias racistas descritas neste Artigo são cientificamente falsas, moralmente censuráveis, socialmente injustas e contrárias aos princípios fundamentais do Direito Internacional e, portanto, perturbam gravemente a paz e a segurança internacional, sendo, dessa maneira, condenadas pelos Estados Partes. 5. As medidas especiais ou de ação afirmativa adotadas com a finalidade de assegurar o gozo ou exercício, em condições de igualdade, de um ou mais direitos humanos e liberdades fundamentais de grupos que requeiram essa proteção não constituirão discriminação racial, desde que essas medidas não levem à manutenção de direitos separados para grupos diferentes e não se perpetuem uma vez alcançados seus objetivos. 6. Intolerância é um ato ou conjunto de atos ou manifestações que denotam desrespeito, rejeição ou desprezo à dignidade, 
pesquisas sobre o genoma humano para seleção ou clonagem humana que gere discriminações fundadas em características genéticas (art. 4ํ5).

Nesse ano de 2016, a OEA aprovou a Declaração Americana sobre os direitos dos Povos Indígenas, que destaca a importância da jurisdição de cada Estado conduza o direito das pessoas indígenas com direito de plena representação com dignidade e igualdade frente à lei (art. XXI), bem como que os direitos da convenção sejam um standard mínimo para sua sobrevivência, dignidade e bem-estar (art. XLI). Essa declaração e a jurisprudência em matéria de direitos indígenas colocam em evidência os limites, dado o caráter inevitavelmente antropocêntrico, de pensar a dignidade da pessoa humana como chave central dos direitos humanos fundamentais. É preciso de um lado acentuar a dimensão do reconhecimento para incluir a proteção desse grupo vulnerável e, de outro, pensar em outras chaves que incluam cosmologias biocêntricas ou geocêntricas. ${ }^{46}$

\section{A jurisprudência da Corte Interamericana de Direitos Humanos}

A maioria dos casos da Corte Interamericana de Direitos Humanos que emprega explicitamente a "dignidade da pessoa humana" como argumento versam sobre a violência contra detentos, o encarceramento em condições desumanas, desaparecimentos forçados e execuções extrajudiciais. A pesquisa até abril de 2016 com o critério "dignidad" revela 158 manifestações da Corte IDH, dentre as quais há 48 casos contenciosos, 16 medidas provisórias e 65 supervisões de sentença. Não pretendemos realizar uma análise exaustiva do uso da dignidade da pessoa humana em cada uma dessas decisões. Tomaremos apenas algumas

características, convicções ou opiniões de pessoas por serem diferentes ou contrárias. Pode manifestarse como a marginalização e a exclusão de grupos em condições de vulnerabilidade da participação em qualquer esfera da vida pública ou privada ou como violência contra esses grupos".

45 Convenção Interamericana contra o Racismo, a Discriminação Racial e Formas Correlatas de Intolerância de 2013, “Artigo 4 Os Estados comprometem-se a prevenir, eliminar, proibir e punir, de acordo com suas normas constitucionais e com as disposições desta Convenção, todos os atos e manifestações de racismo, discriminação racial e formas correlatas de intolerância, inclusive: (...) xiii. realização de pesquisas ou aplicação dos resultados de pesquisas sobre o genoma humano, especialmente nas áreas da biologia, genética e medicina, com vistas à seleção ou à clonagem humana, que extrapolem o respeito aos direitos humanos, às liberdades fundamentais e à dignidade humana, gerando qualquer forma de discriminação fundamentada em características genéticas".

46 A esse respeito, seria positiva uma maior aproximação da Corte IDH com a experiência das Constituições e jurisprudência da Corte Constitucional do Equador e do Tribunal Plurinacional da Bolívia com a pachamama, a mãe terra nesse sentido é promissora. A Corte IDH deveria ampliar o diálogo com essa literatura e jurisprudência quando se deparar com direitos dos povos originários. Cf. LEGALE, Siddharta. O que é a vida nas Cortes do novo constitucionalismo latino-americano. Publicum, n. 2, 2016. Disponível em: <http://www.e-publicacoes.uerj.br/index.php/publicum/article/view/23684>. 
decisões como metonímias da compreensão da Corte Interamericana em suas múltiplas dimensões.

Destacamos, preliminarmente, apenas que é possível achar outros temas além dos mais comuns mencionados acima. Os temas escolhidos envolvem de forma indissociável as três dimensões apontadas para a dignidade, quais sejam, valor intrínseco, autonomia e reconhecimento de direitos de certos grupos vulneráveis. Apenas para fins didáticos, agruparemos a seguir os casos nesses três eixos da dignidade, ressaltando o elemento preponderante em cada um deles. Selecionaremos casos sobre temáticas, anos, relatores e espécies de decisão diferentes, que sejam capazes de fornecer uma visão geral da forma como a Corte Interamericana aplica a dignidade da pessoa humana.

Em relação ao valor intrínseco, é possível destacar o caso Velazquez Rodriguez vs. Honduras (1988). ${ }^{47}$ A Corte IDH vedou o tratamento cruel e desumano, com base no art. 5ํ da Convenção Americana, por entender que a prática sistemática do Estado de desaparecer com as pessoas violava a dignidade humana. Afirmou que "Nenhuma atividade do Estado pode fundar-se sobre o desprezo à dignidade humana". O isolamento e a total falta de comunicação do preso constituem uma ofensa à dignidade que Ihe é inerente. 0 valor inerente à pessoa humana, portanto, pressupõe o respeito e proteção permanente pelo Estado. Não se trata de uma exigência episódica, pontual ou circunstancial. Nem mesmo o fato de alguém haver cometido um crime, por mais grave que seja, permite ou deve permitir que o Estado Ihe dispa da dignidade. Reitere-se: dignidade essa que é inerente a qualquer ser humano. ${ }^{48}$

No caso Presídio Miguel Castro vs Peru (2006), a Corte IDH responsabilizou o Estado peruano pela violação dos direitos humanos em prejuízo de 42 detentos que faleceram, 175 detentos que ficaram feridos e 322 detentos que foram submetidos a tratamento cruel, desumano e degradante, inclusive em relação às reclusas que permaneceram durante prolongado período de nudez forçada. Os detentos e seus familiares foram tratados como terroristas, havendo uma intervenção policial desproporcional, sem que sequer houvesse rebelião ou motim.

Em denso voto concorrente, refletindo sobre a violência crônica e generalizada do caso que envolveu a prisão de integrantes do grupo chamada Sendero Luminoso, Cançado Trindade discorre sobre a importância para se atribuir o primado do direito em relação à força, da justiça em relação à vingança privada. Destacou o acesso direto à justiça como um imperativo do jus cogens. Talvez

47 Em sentido semelhante, confira-se: Neira Alegría e outros vs. Peru (1995).

48 MONSALVE, Viviana Bohórquez; e ROMÁN, Javier Aguirre. As tensões da dignidade humana: conceituação e aplicação no direito internacional dos direitos humanos. SUR, v. 6, n. 11, p. 53, 2009. 
esse seja o voto que melhor reflete expressamente sobre o conceito de dignidade da pessoa humana no sistema interamericano. A partir do pensamento kantiano, afirma:

Se pode daqui extrair algumas ilações. Em primeiro lugar, o imperativo kantiano está sempre presente, quando se trata de defender e preservar a dignidade da pessoa humana, a dignidade de sua própria humanidade. Em segundo lugar, incide em todas as esferas de relacionamento humano, tanto nas relações de um com agentes do poder público ou estatal, como com outros seres humanos, com particulares. Em terceiro lugar, pode ser invocado na proteção de cada pessoa humana isoladamente, assim como de grupos de pessoas ameaçadas ou lesionadas. E, em quarto lugar, pode ser invocado na salvaguarda de distintos direitos humanos a ser protegidos. (Tradução livre)

Perceba-se que as três dimensões, pontuadas pelo Juiz Cançado Trindade, identificam-se perfeitamente com as dimensões referidas anteriormente: (i) valor intrínseco com a "dignidade de sua própria humanidade"; (ii) autonomia para as relações "com agentes do poder público ou estatal, como com outros seres humanos, com particulares"; e (iii) reconhecimento com "grupo de pessoas ameaçados ou lesionados" para salvaguarda de diferentes direitos humanos.

Em passagem particularmente sensível do voto, Cançado Trindade destaca que um Tribunal Internacional como a Corte Interamericana não diz apenas o direito, mas realiza a justiça e restaura a dignidade das vítimas. Para tanto, porém, deve ser capaz de permitir o acesso às vítimas, que falem livremente, que sejam ouvidas, como uma forma de restaurar a justiça. Atente-se para o fato de que o acesso à justiça nessa hipótese não é apenas instrumental, mas uma das formas próprias de reparação da dignidade das vítimas ao serem ouvidas. A vítima vê reconhecida a sua condição de sujeito de direito a partir de sua própria voz.

Em 2014, a Corte deferiu uma medida provisória em relação ao Presídio de Pedrinhas no Maranhão onde estavam acontecendo violações gravíssimas à dignidade da pessoa humana em sua dimensão nuclear. Houve decapitações, dissecação de uma perna, perfurações, disseminação de AIDS, tuberculose e lepra no ano de 2013. Poderíamos ser levados a crer que estamos em uma "masmorra medieval" 49 pelas condições aviltantes ao valor inerente ao ser humano.

49 Como bem destacou o prof. Daniel Sarmento, lembrando a fala do Ministro da Justiça José Eduardo Cardoso, a situação dos presídios no Brasil é sem exagero semelhante às "masmorras medievais" ou “infernos dantescos”. O cenário é composto por "celas superlotadas, imundas e insalubres, proliferação de doenças infectocontagiosas, comida intragável, temperaturas extremas, falta de água potável e de 
O local, porém, é mesmo um Presídio no Maranhão. Os fatos foram amplamente noticiados na mídia inclusive com vídeos e fotos. Infelizmente, não se trata de um caso atual ou isolado. O Brasil já foi condenado por violação de direitos pela Corte Interamericana no caso do Presídio Urso Branco em Rondônia por conta de uma chacina em 2002, bem como por mortes decorrentes de uma rebelião no Presídio de Curado em Pernambuco em 2013, que inclusive estão sendo também objeto de medidas provisórias pela Corte Interamericana. Onze anos se passaram. Mudou o presídio, mas permanece - ou talvez tenha se agravado - o dramático quadro de violação aos direitos humanos fundamentais.

O caso teve ensejo com pedido da Comissão Interamericana de Direitos Humanos à Corte Interamericana para que fossem adotadas medidas provisórias, nos termos do art. 63, 2 da Convenção Americana de Direitos Humanos, com o objetivo de preservar os direitos fundamentais à vida e à integridade física dos presos em função da superlotação, assassinatos, torturas, atos de extrema violência e violações graves à integridade física dos presos pelos próprios presos, por agentes privados responsáveis pela vigilância e monitoramento dos presídios e por agentes públicos.

A Comissão Interamericana solicitou a adoção de medidas que logrem o efetivo controle do Centro Penitenciário em respeito aos direitos humanos das pessoas privadas de liberdade, como, por exemplo, a identificação e eliminação do tráfico de armas no interior do presídio, a diminuição dos elevados índices de superlotação e, ainda, a prestação de serviços de saúde, especialmente aos reclusos portadores de enfermidades contagiosas de modo a evitar a propagação das mesmas.

Por essa razão, a Corte Interamericana determinou que fossem adotadas e monitoradas as providências para garantir a vida, integridade pessoal e "condições de detenção mínimas compativeis com sua dignidade", inclusive com a obrigação de o estado informar os avanços a cada três meses.

Em relação à autonomia, destaco o caso Artavia Murillo Y Otros vs. Costa Rica (2012) pelas importantes reflexões sobre a dignidade humana e a autonomia privada da mulher. A Corte IDH analisou demandas de uma série de casais que se viram proibidos de realizar "fertilização in vitro" por um decreto do Poder Executivo na Costa Rica. O Estado alegou que permitir o procedimento violaria a vida e a dignidade dos embriões descartados no processo. Ao analisar a questão, recorrendo à literatura médica e aos tratados preparatórios da Convenção Americana de Direitos Humanos, a Corte Interamericana explicitou o significado de pessoa 
nas expressões “toda pessoa”, presentes em seu interior, especialmente do art. $4^{\circ}$, referente ao direito à vida. Concluiu, por uma interpretação histórica e sistemática, que o embrião, resultado da fecundação entre óvulo e espermatozoide, não é pessoa, porque essa só ocorre a partir da concepção dentro do corpo da mulher.

A Corte, sob essa premissa, entendeu que não se sustenta um direito absoluto à vida do embrião em detrimento da autonomia de ter filhos por meio da reprodução assistida como uma parte dos direitos à integridade, liberdade e vida privada e familiar. Vale lembrar que, no art. 11 da Convenção Americana, dignidade e vida privada constam no mesmo dispositivo, prevendo a impossibilidade de ingerências arbitrárias ou abusivas. Passou a analisar, por isso, a proporcionalidade da intervenção restritiva estatal, rechaçando-a por propiciar um impacto desproporcional que, embora afete tanto homens quanto mulheres inférteis, acaba por possuir um impacto diferenciado nas mulheres, contribuindo para uma visão estereotipada. Consignou, ainda, que o fato de se perder alguns embriões, como, aliás, não raro acontece na gravidez natural, não pode ser justificativa para a proibição. Em passagem, particularmente inspirada do acórdão, fica clara essa relação entre autonomia, vida privada e dignidade:

A proteção da vida privada abarca uma série de fatores relacionados com a dignidade do indivíduo, incluindo, por exemplo, a capacidade para desenvolver a própria personalidade e aspirações, determinar sua própria identidade e definir suas próprias relações pessoais. 0 conceito de vida privada engloba aspectos da identidade física e social, incluindo o direito a autonomia pessoal, desenvolvimento pessoal e o direito a estabelecer e desenvolver relações com outros seres humanos e com o mundo exterior. A efetividade do exercício do direito à vida privada é decisiva para a possibilidade de exercer a autonomia pessoal sobre o futuro curso de eventos relevantes para a qualidade de vida da pessoa. A vida privada inclui a forma em que o indivíduo vê a si mesmo e como decide projetar-se para os demais, e é uma condição indispensável para o livre desenvolvimento da personalidade. Além do mais, a Corte tem destacado que a maternidade forma parte essencial do livre desenvolvimento da personalidade das mulheres. (Tradução livre)

Note-se, no trecho em destaque, que a dignidade pressupõe o exercício da autonomia privada, da "capacidade para desenvolver a própria personalidade e aspirações”, o que, no caso em questão, envolve a possibilidade de lançar mão dos progressos científicos para aprimorar a sua qualidade de vida e exercer a maternidade ou a paternidade. 
Quanto ao aspecto que relaciona a dignidade com a autonomia pública, é possível ilustrar a problemática com o caso Vélez Restrepo y familiares vs. Colombia (2012). O jornalista Luis Gonzalo Vélez Restrepo cobria uma manifestação na Colômbia em que a população se insurgia contra a política governamental referente ao cultivo de coca. Durante protesto, houve conflito entre membros do exército nacional e os manifestantes. Enquanto filmava a manifestação, o jornalista flagrou uma cena de abuso em que os militares violentavam um civil indefeso. Ao perceberem, os militares se dirigiram ao cinegrafista e, de forma truculenta, tomaram seu equipamento, destruindo-o completamente. Além disso, efetuaram uma série de agressões físicas e morais ao ofendido. Apesar da tentativa de se desvencilharem da fita, recuperou-se a gravação em que praticamente toda ação foi gravada, sendo exibida em rede nacional.

Posteriormente, o senhor Vélez e sua família se tornaram alvos constantes de intimidações e ameaças de morte. A situação se tornou ainda mais grave após uma tentativa de sequestro contra ele. Apesar das medidas protetivas do estado, Vélez decidiu que sua permanência, e de sua família, no país era insustentável. As medidas protetivas atribuídas não seriam capazes de resguardar sua integridade física e de sua família. O Estado da Colômbia reconheceu parte de sua responsabilidade internacional perante a Corte Interamericana.

A CIDH decidiu que a atuação do estado da Colômbia foi negligente ao não atuar de forma devida na investigação e condenação dos culpados. A omissão da justiça configurou lesão direta à própria liberdade de expressão, princípio consagrado pela Convenção. O interesse público está diretamente relacionado com a necessidade de difusão de informações sem qualquer tipo de interferência, tampouco, coerção por parte do Estado. A livre formação de opinião decorre da autonomia individual e política do cidadão, revelando-se imprescindível para a proteção de direitos fundamentais e do princípio democrático. A formação da opinião coletiva pressupõe a garantia estatal da idoneidade e do livre desenvolvimento de funções essenciais, como a imprensa. ${ }^{50} \mathrm{~A}$ dignidade relaciona-se justamente à autonomia pública. A Corte determinou a indenização como medidas de reparação pelos danos materiais e imateriais ao jornalista, mais especificamente, por violação à sua liberdade de expressão, honra, profissão e dignidade.

Em relação ao reconhecimento, vale ressaltar que a Corte Interamericana costuma dedicar particular atenção a grupos de pessoas em situação de vulnerabilidade: mulheres, deficientes, pessoas em deslocamento forçado, indígenas,

50 Vale lembrar a Opinião Consultiva no 3/85, segundo a qual o registro obrigatório do jornalista pode impedir o acesso aos meios de comunicação social como veículo para se expressar ou para transmitir informação é incompatível com o artigo 13 sobre os direitos humanos. 
crianças de rua etc. ${ }^{51}$ Essa é, por assim dizer, a dimensão intersubjetiva da dignidade da pessoa humana no sistema interamericano.

Um caso particularmente relevante para compreender essa dimensão da dignidade da pessoa humana é Villagrán Morales e outros vs. Guatemala, conhecido como Meninos de Rua vs. Guatemala (1999), que envolveu a tortura, sequestro e assassinato de cinco jovens, dentre eles dois menores, que viviam nas ruas. Foram colocados no porta-malas do carro e depois assassinados em uma região conhecida como "Las casetas". A Corte Interamericana reconheceu a omissão do Estado na investigação para localizar os responsáveis.

Constata-se, além da violação ao valor inerente à vida humana, que veda a tortura nos termos do art. 5ำ da Convenção Americana, também a violação da dignidade humana das crianças, prevista na Convenção sobre direitos da criança, especialmente os arts. $28^{52}$ e $37 . .^{53}$ Sobressaem do caso dois elementos que a Corte tem utilizado para identificar e definir a violação à dignidade humana, quais sejam, (i) condições especiais de vulnerabilidade das pessoas; e (ii) contexto dos fatos violadores. Em cuidadoso voto concorrente, Cançado Trindade e Abreu Burelli, após consignarem que o direito à vida integra jus cogens, afirmam:

O dever do Estado de tomar medidas positivas se acentua precisamente em relação com a proteção da vida de pessoas vulneráveis e indefesas, em situação de risco, como são os meninos de rua. A privação arbitrária da vida não se limita, pois, ao ilícito do homicídio; se estende igualmente a privação do direito de viver com dignidade. Essa visão conceitua o direito à vida como pertencente, ao mesmo tempo, ao domínio dos direitos civis e políticos, assim como os direitos econômicos, sociais e culturais, ilustrando assim a inter-relação e indivisibilidade de todos os direitos humanos. (Tradução livre)

51 Vale a pena conferir, a propósito, o inspirado capítulo 9 de: CANÇADO TRINDADE, Antônio Augusto. The access of individuals to international justice. Oxford: Oxford University Press, 2011.

52 Convenção sobre os direitos da Criança (1990): “Artigo 28 1. Os Estados Partes reconhecem o direito da criança à educação e, a fim de que ela possa exercer progressivamente e em igualdade de condições esse direito, deverão especialmente: (...) 2. Os Estados-Partes adotarão todas as medidas necessárias para assegurar que a disciplina escolar seja ministrada de maneira compatível com a dignidade humana da criança e em conformidade com a presente convenção".

53 Convenção sobre os direitos da Criança (1990): “Artigo 37 Os Estados Partes zelarão para que: (...) c) toda criança privada da liberdade seja tratada com a humanidade e o respeito que merece a dignidade inerente à pessoa humana, e levando-se em consideração as necessidades de uma pessoa de sua idade. Em especial, toda criança privada de sua liberdade ficará separada dos adultos, a não ser que tal fato seja considerado contrário aos melhores interesses da criança, e terá direito a manter contato com sua família por meio de correspondência ou de visitas, salvo em circunstâncias excepcionais". 
Note-se que o direito à vida aqui foi tomado não apenas como o direito à existência, mas o direito de viver com dignidade e de que o seu projeto existencial não seja inviabilizado, o que é particularmente sensível na infância e adolescência a exigir uma concepção interdependente de todos os direitos humanos.

No caso Comunidade Mayagna (Sumo) Awas Tingni vs. Nicaragua (2001), a Corte Interamericana reconheceu que a ocupação tradicional e os recursos naturais da comunidade indígena deveriam ser respeitados. Condenou o Estado por outorgar um contrato de concessão florestal de madeira em seu território sem sequer ouvir a comunidade. 0 fato violou uma combinação de direitos, como, por exemplo, o direito à vida, honra, dignidade e propriedade. Determinou-se a criação de um mecanismo efetivo para delimitar, demarcar e conferir titularidade das propriedades das comunidades indígenas, de acordo com seu direito costumeiro, valores e usos.

Determinou, ainda, que, enquanto não ocorrer tal demarcação, deve se proceder com a sua aquiescência e tolerância, de modo a não afetar seus valores e gozo dos bens na região geográfica, chegando a citar, para tanto, o art. 5ㅇ da Constituição da Nicarágua de 1995, que prevê o respeito à dignidade da pessoa humana, o pluralismo político, social e étnico, bem como o reconhecimento das distintas formas de propriedade. Chegou-se a reconhecer não só o dano material, mas também imaterial à comunidade a ser reparado por meio de obras de interesse coletivo na comunidade.

Note-se que a delimitação da propriedade, a necessidade de aquiescência do indígena e o reconhecimento do dano imaterial procuram proteger e modificar a própria maneira de perceber e lidar com os indígenas, conferindo-lhes igual respeito e consideração, que constituem importantes elementos da dignidade como reconhecimento.

Em interessante voto concorrente, o juiz Sérgio Ramírez relaciona o princípio pro homine, da norma mais favorável ao indivíduo, à proteção da dignidade da pessoa humana. Destaca esse como o objeto e finalidade da Convenção Americana, que se concentra no reconhecimento da dignidade humana e das necessidades de proteção e desenvolvimento das pessoas. Sopesa, que, apesar de existirem variados conceitos de propriedade na América, é preciso atentar para a Convenção no 169 da OIT, para o projeto de declaração sobre a discriminação contra populações indígenas e para o projeto de declaração americana sobre direitos dos povos indígenas.

Esses documentos procuram preservar e fortalecer a relação própria espiritual e material dos indígenas com suas terras, territórios, águas, mares. Estabelecer esse respeito à propriedade comunal é relevante nos países da América Latina, que vivenciaram um processo de liquidação desse tipo de propriedade, de governos autônomos dos povos indígenas e de desaparecimento físico e cultural, de modo a resgatar, preservar e desenvolver um maior respeito à dignidade como reconhecimento dos indígenas. 
O caso Atala Riffo e filhas vs. Chile (2012), por sua vez, retrata uma importante dimensão da dignidade humana, relacionada ao reconhecimento dos direitos da população LGBTI. Os fatos envolvem a perda da guarda da senhora Karen Atala Riffo de suas três filhas para o pai das meninas. A ação foi proposta pelo pai logo após a sua separação, mais especificamente após a mãe assumir uma relação homossexual e passar a dividir a casa com a sua companheira e as três filhas. A Corte Suprema de Justiça do Chile havia fundamentado a decisão alegando a discriminação que as filhas poderiam sofrer em seu meio social, a confusão das filhas sobre a sexualidade e o impacto sobre os interesses das filhas. A Corte Interamericana destacou não se tratar de uma mera questão de custódia das filhas, que seria um tema de direito interno. Registrou que as autoridades públicas violaram os direitos humanos, em especial a igualdade e não discriminação. Destacou que esse princípio ingressou no campo do jus cogens e que o art. $1^{\circ}$ da Convenção americana ao listar as formas discriminação não é taxativo.

A fundamentação foi bastante densa, iniciando pela necessidade de a Convenção ser interpretada de forma evolutiva e mais protetiva às vítimas para incluir a proteção contra a discriminação decorrente da orientação sexual. Em primeiro lugar, o "interesse superior da criança" não pode servir para reproduzir um "estigma social", tal como o de considerar a mudança de orientação sexual da mãe, como um dano válido ao desenvolvimento da criança por supostamente causar confusão da orientação sexual. Em segundo lugar, a Convenção Americana não protege um modelo específico de família, não podendo essa ser reduzida à "família tradicional" dentro do matrimônio. Em terceiro lugar, os processos de investigação, inclusive nos locais de trabalho, para constatar a orientação sexual da mãe, representaram uma ingerência abusiva e desproporcional em seu direito à vida privada, honra e a dignidade, previsto no art. 11 da Convenção Americana.

Por fim, a Corte Interamericana determinou a indenização por danos materiais, danos morais, assistência médica e psicológica às vítimas de discriminação. Consignou a responsabilidade internacional do Estado, fixando a obrigação de realizar um ato de desagravo público. Impôs, ainda, mudanças na legislação, adoção de políticas públicas e outras medidas que capacitem as autoridades públicas, inclusive judiciais para, a um só tempo, manter um ambiente de tolerância contra minorias sexuais invisibilizadas e promover mudanças estruturais que ajudem a desarticular estereótipos e práticas discriminatórias contra a população LGBTI.

\section{Conclusão}

Em desfecho, pretende-se compendiar as principais ideias do texto em formulações sintéticas. 
Na relação entre filosofia e direito, é possível estabelecer os seguintes elementos como integrantes centrais de um conteúdo interamericano para o princípio da dignidade da pessoa humana: (a) valor intrínseco; (ii) autonomia; e (iii) reconhecimento.

Nos tratados de direitos humanos do sistema interamericano, a dignidade aparece especialmente nos preâmbulos das declarações, o que indica que a "dignidade", a "pessoa humana", "direitos da pessoa", "dignidade da pessoa humana", "dignidade inerente à pessoa humana" ou apenas o "ser humano" desempenha uma importância central na interpretação de todos os direitos humanos fundamentais.

Não obstante, a dignidade consta no corpo de diversos tratados ao lado de direitos fundamentais variados, como a propriedade (Declaração Americana de Direitos e Deveres do homem de 1948), a vida, integridade física e honra (Convenção Americana de Direitos Humanos de 1969), educação (Pacto de San Salvador de 1988) e direitos variados de grupos em condições de vulnerabilidade de direitos, como a mulher (Convenção de Belém do Pará de 1994) e dos indígenas (Declaração Americana sobre os Direitos dos Povos Indígenas).

A jurisprudência da Corte Interamericana de Direitos Humanos costuma empregar pouco a dignidade como argumento autônomo. Em geral, a dignidade vem acoplada com outro direito fundamental específico. Ainda assim, é possível constatar contornos próprios do conceito a partir de uma leitura de sua jurisprudência.

Em relação ao valor intrínseco, costuma-se empregar normalmente como a ideia de "valor inerente ao ser humano" ou de "dignidade de sua própria humanidade", como em geral se verifica nas violações a direitos humanos dos encarcerados, tal como se deu nos casos Velazquez Rodriguez vs Honduras (1988), Presídio Miguel Castro vs Peru (2006) e as medidas provisórias em relação ao Presídio de Pedrinhas no Brasil (2014).

Em relação à autonomia, a Corte destaca a importância do livre desenvolvimento da personalidade, seja nas relações entre particulares, seja com agentes do poder público ou estatal. Nesse sentindo, o caso Artavia Murillo Y Otros vs. Costa Rica (2012) é particularmente relevante na construção da dignidade da mulher como autonomia reprodutiva.

A dimensão mais interessante da dignidade da pessoa humana no sistema interamericano é a relaciona ao reconhecimento, ao respeito aos projetos existenciais e não apenas ao direito à vida de um "grupo de pessoas ameaçados ou lesionados" ou de grupos de "pessoas em situação de vulnerabilidade" para salvaguarda de diferentes direitos humanos, por exemplo, das mulheres (Atala Riffo e filhas vs. Chile de 2012), das crianças de rua (Villagrán Morales e outros vs. Guatemala de1999) e indígenas (Comunidade Mayagna Sumo Awas Tingni vs. Nicaragua de 2001). 
Destaque-se, por fim, que, embora os casos tenham sido escolhidos de forma exemplificativa, eles fornecem a exata dimensão de que, para além do valor intrínseco e do respeito à autonomia estarem presentes no discurso da Corte Interamericana, é a ideia de vulnerabilidade (ou de situações de vulnerabilidade) que opera como o fio condutor e diferencial interpretativo que particulariza não só a dimensão intersubjetiva ou de reconhecimento da dignidade da pessoa humana, mas a própria maneira de compreender a dignidade da pessoa humana no sistema interamericano.

\title{
The Human Dignity and the Case Law of Inter-American Court of Human Rights
}

\begin{abstract}
The Inter-American content of the principle of human dignity will be study in human rights treaties and in the case law of the IACHR. Human dignity normally is in the preambles of treaties in this way: "inherent in the human person." The human dignity appears next of other fundamental rights, such as property, life, honor, education and rights groups in vulnerable conditions, such as women and indigenous. The case law of the Inter-American Court of Human Rights seldom employs the human dignity itself without reference of other human right.
\end{abstract}

Keywords: Human Dignity and Inter-American Court of Human Rights.

Summary: $\mathbf{1}$ Introduction - $\mathbf{2}$ From philosophy to law: human dignity as a legal principle - $\mathbf{3}$ The human dignity in the inter-American system for the protection of human rights $\mathbf{- 4}$ The case law of the InterAmerican Court - $\mathbf{5}$ Conclusion - References

\section{Referências}

BARCELLOS, Ana Paula de. A eficácia jurídica dos princípios constitucionais: o princípio da dignidade da pessoa humana. Rio de Janeiro: Renovar, 2002

BARROSO, Luís Roberto. A dignidade da pessoa humana no direito constitucional contemporâneo: a construção de um conceito jurídico à luz da jurisprudência mundial. Belo Horizonte: Fórum, 2014.

BARROSO, Luís Roberto. Aqui, lá e em todo lugar: a dignidade da pessoa humana no direito contemporâneo e no discurso transnacional. Revista dos Tribunais, v. 919, p. 127-196, n. 2012.

CANÇADO TRINDADE, Antônio Augusto. L'expansion de la juridiction internationale et la sauvegarde de la dignité humaine. In: CANÇADO TRINDADE, Antônio Augusto; LEAL, César Barros (Coord.). Le respect de la dignité humaine: IV Cours Brésilien interdisciplnaire em Droits de I'homme. Fortaleza: IBDH, 2015.

CASSETTI, Luisa. II diritto di "vivere con dignità" nella giurisprudenza della Corte Interamericana dei Diritti Umani. Disponível em: <http://www.unipv-lawtech.eu/lang1/files/vivereCONdignita.pdf>.

KANT, Immanuel. Fundamentação da metafísica dos costumes. Trad. Paulo Quintela. Coimbra: Edições 70, 1948.

KANT, Immanuel. A metafisica dos costumes. Trad. Edson Bini. Bauru: Edipro, 2008. 
HABERMAS, Jurgen. Sobre a coesão interna entre Estado de direito e democracia. In: $A$ inclusão do outro, estudos de teoria política. São Paulo: Edições Loyola, 2007.

HESSE, Konrad. Elementos de direito constitucional da República Federal da Alemanha. Porto Alegre: Sergio Antonio de Fabris, 1998.

LOBO TORRES, Ricardo. O direito ao mínimo existencial. Rio de Janeiro: Renovar, 2009.

MCCRUDDEN, Christopher. Human Dignity and Judicial Interpretation of Human Rights. The European Journal of International Law, v. 19 n. 4, 2008.

MONSALVE, Viviana Bohórquez; ROMÁN, Javier Aguirre. As tensões da dignidade humana: conceituação e aplicação no direito internacional dos direitos humanos. SUR v. 6, n. 11, p. 41-63, 2009.

LEGALE, Siddharta. O que é a vida nas Cortes do novo constitucionalismo latino-americano. Publicum, n. 2, 2016. Disponivel em: <http://www.e-publicacoes.uerj.br/index.php/publicum/ article/view/23684>.

PIEROTH, Bodo; SCHLINK, Bernhard. Direitos fundamentais. São Paulo: Saraiva, 2012.

PIOVESAN, Flávia; VIEIRA, Renato Stanziola. A força normativa dos princípios constitucionais fundamentais: a dignidade da pessoa humana. In: PIOVESAN, Flávia (Org.). Temas de direitos humanos. São Paulo: Saraiva, 2010

RAWLS, John. Uma teoria da justiça. São Paulo: Martins Fontes, 2008.

RAWLS, John. Justiça como equidade: uma reformulação. São Paulo: Martins Fontes, 2003.

SARLET, Ingo. Comentário ao art. 1ํ, III. In: CANOTILHO, J.J. et al. Comentários à Constituição do Brasil. São Paulo: Saraiva/Almedina, 2013, p 121 e ss.

SARLET, Ingo. As dimensões da dignidade da pessoa humana: construindo uma compreensão jurídico constitucional necessária e possível Revista Brasileira de Direito Constitucional $R B D C$, n. 09, jan./jun. 2007.

SARMENTO, Daniel. Dignidade da pessoa humana na ordem constitucional brasileira: conteúdo, trajetórias e metodologia. Rio de Janeiro: Tese de Titularidade de Direito Constitucional da UERJ, 2015.

SILVA, José Afonso da. A dignidade da pessoa humana como valor supremo da democracia. In: Poder constituinte e poder popular. São Paulo: Malheiros, 2007.

Informação bibliográfica deste texto, conforme a NBR 6023:2002 da Associação Brasileira de Normas Técnicas (ABNT):

LEGALE, Siddharta; VAL, Eduardo Manuel. A dignidade da pessoa humana e a jurisprudência da Corte Interamericana de Direitos Humanos. Direitos Fundamentais \& Justiça, Belo Horizonte, ano 11, n. 36, p. 175-202, jan./jun. 2017.

Recebido em: 01.11.2016

Pareceres: 30.11.2016 e 08.12.2016

Aprovado em: 14.12.2016 